Available online at GSC Online Press Directory

GSC Biological and Pharmaceutical Sciences

e-ISSN: 2581-3250, CODEN (USA): GBPSC2

Journal homepage: https://www.gsconlinepress.com/journals/gscbps

(RESEARCH ARTICLE)

\title{
Phytochemicals and phyto-disinfectant properties of citrus species (Citrus limon, Citrus aurantifolia and Citrus sinensis) for pond water purification
}

\author{
Okunlola Banke Mary ${ }^{1,}{ }^{*}$, Ijah Udeme Joshua Josiah ${ }^{1}$, Yisa Jonathan ${ }^{2}$ and Abioye Olabisi Peter ${ }^{1}$ \\ ${ }_{1}^{1}$ Department of Microbiology, Federal University of Technology, Minna, Niger State. \\ ${ }^{2}$ Department of Chemistry, Federal University of Technology, Minna, Niger State.
}

Publication history: Received on 27 July 2019; revised on 12 August 2019; accepted on 14 August 2019

Article DOI: https://doi.org/10.30574/gscbps.2019.8.2.0139

\begin{abstract}
The health concern associated with the use of chemical disinfectant in water purification has necessitated the search of safe and effective water treatment agents from natural sources. The leaf, stem, seed and bark of Citrus limon, Citrus aurantifolia and Citrus sinensis were investigated for phytochemicals and disinfectant properties on contaminated pond water at concentrations of $0.1,0.2,0.3,0.4$ and $0.5 \mathrm{~g} / \mathrm{L}$. Microbial quality of the water sample was investigated at $12 \mathrm{hrs}$ interval. The leaf and bark of C. aurantifolia and the bark of $C$. limon contains all the phytochemicals tested. Steroids and alkaloids were present in all parts of the plant. Cardiac glycosides and terpenes were present in all parts of Citrus sinensis. A total of 10 different bacteria isolates were identified from ponds water sample. The stem of Citrus aurantifolia completely eliminated the total viable count, total coliform count, fecal coliform count after $12 \mathrm{~h}$. The leaf, bark and seed of C. aurantifolia at $0.3,0.4$ and $0.5 \mathrm{~g} / \mathrm{L}$, leaf and bark of $C$. limon and $C$. sinensis at $0.1-0.5 \mathrm{~g} / \mathrm{L}$ eliminated the various bacteria after 24 hours. However, the stem and seed of $C$. limon were less active; only concentrations of 0.4 and $0.5 \mathrm{~g} / \mathrm{L}$ eliminated the organism after $24 \mathrm{~h}$ of treatment. The plant materials had minimum inhibitory concentration in the ranged of 16 and $128 \mathrm{mg} / \mathrm{g}$ and minimum bactericidal concentrations in the ranged 16 and $256 \mathrm{mg} / \mathrm{g}$ against all the isolates. It is concluded that the leaf, stem bark and seed of citrus species contains various phytochemicals and have the potentials to serve as a disinfectant for water treatment.
\end{abstract}

Keywords: Antimicrobial; Citrus limon; Citrus aurantifolia; Citrus sinensis; Drinking water; Phytochemicals

\section{Introduction}

Drinking water is indispensable for human existence, it is used to meet up the basic human need including food, shelter and clothing, thus serve as essential ingredients for wellbeing and a healthy life [1]. Some rural and urban area of Nigeria suffers a severe drinking water supply crisis, particularly in the dry seasons of every year. The drinking water supplies in the cities is intermittent. Nearly all of the surface sources and ground water sources have been exploited. The growing imbalance between supply and demand has led to chronic shortages and competition that have resulted in pollution and environmental degradation. Apart from quantitative shortages, the quality of drinking water in the rural and urban area of the country is becoming a serious public health issue for the past few years [2]. The quality of water for drinking has deteriorated because of the treatment inadequacy, direct discharge of untreated sewage into rivers, ponds and inefficient management of the piped water distribution system [3].

Diarrhoea, typhoid fever, and cholera are caused by poor sanitation, hygiene and water quality, are one of the most prevalent water borne disease in Nigeria. Ideally, drinking water should not contain any microorganisms known to be pathogenic or any bacteria indicative of faecal pollution [4]. The world health organization has estimated that up to $80 \%$ of all diseases and sickness in the world is caused by inadequate sanitation, polluted water or unavailability of water

\footnotetext{
${ }^{*}$ Corresponding author

E-mail address: bankeokunlola@gmail.com
} 
however, $10 \%$ could be prevented by improvements related to drinking water, sanitation, hygiene and water resource management [5]. Larger populations of Nigerians depend on raw water for drinking purposes without any treatment whatsoever.

Africa is endowed with large amounts of medicinal plants with important source of active ingredients which differ widely in terms of structure and therapeutic properties [6-8]. The importance of plants as antimicrobial remains of greater relevance with the current global shift to obtain remedies from plants sources owing to their safety, efficacy and availability [9-10]

Indigenous knowledge indicates that there are several plant species that can be used as a water disinfectant [11]. Recent studies have also indicated the efficiency of various plants seed on surface water purification [11-12]. However, less attention has been placed on leaf stem and root of plant. Furthermore, no adequate attention has been given to members of the genus citrus. Citrus is the largest genus belong to the family Rutaceae, it is one of the most essential commercial fruit crops which are grown in all continents of the world [13]. Although sweet orange (Citrus) is the major fruit in this group accounting for about $70 \%$ of citrus output, the group also encompasses small citrus fruits such as Citrus sinensis, lime tree (Citrus aurantifulia) and lemon tree (Citrus limonum) [14]. A large number of plants have been investigated scientifically for antimicrobial activity and a number of citrus plants are rich source of phytochemicals and have been shown to inhibit the growth of pathogenic microorganism [15]. Thus, these plants could serve as a natural disinfectant which are environment friendly and with much reduced risk of handling. The present study therefore, screened Citrus limon, Citrus aurantifolia and Citrus sinensis) for phytochemical composition and their disinfectant potential against microbial population in pond water.

\section{Material and methods}

\subsection{Collection and identification of plant materials}

Seeds, roots, bark and leaves of Citrus limon, Citrus aurantifolia and Citrus sinensis, were collected from Bosso Local Government Area of Minna Niger State based on their uses in water purification and ethno medicine. The plants were identified at and authenticated at NIPRID Abuja where the vouchers numbers NIPRD/H/7024, NIPRD/H/7026 and NIPRD/H/7025 respectively were deposited.

\subsection{Sample preparation and phytochemical analysis}

The leaves, stem, bark and seed samples of Citrus limon, Citrus aurantifolia and Citrus sinensis were washed and dried for 2 weeks $\left(37^{\circ} \mathrm{C}\right)$ and finally grounded using a grinder mill. Quantitative phytochemical analysis of the plant was carried out using standard procedures as described previously [16-17].

\subsection{Collection of water samples and identification of bacterial isolates}

Pond water sample was collected from Chanchaga Local Government Area of Minna, Niger State using Standard sampling methods of APHA [18]. Characterization and identification on isolates was carried out adopting methods of Vandepitte et al. [19] and Cheesbrough [20].

\subsection{Water purification}

The powdered plant material was suspended in the pond water sample at concentrations of $0.1,0.2,0.3,0.4 \mathrm{and} 0.5 \mathrm{~g} / \mathrm{l}$. The treated water was covered, left to settle for an hour and then filtered [21]. The clean water from the solution was then taken after treatment for microbial analysis.

\subsection{Bacteriological analysis of water}

Membrane filtration technique was employed to determine microbial quality of the water samples in accordance with American Public Health Association (APHA). Total viable counts (TVC) were done by plating serially diluted water samples on nutrient agar. All plates were incubated at temperature of $37^{\circ} \mathrm{C}$ for $24 \mathrm{hrs}$. The total coliforms by platting on MacConckey agar, while the fecal coliforms count was performed using most probable number (MPN) method. A broth microdilution method [22], was used to determine the minimum inhibitory concentration (MIC) and minimum bactericidal concentration (MBC) of the extract in triplicates. 


\subsection{Statistical analysis}

Data generated were analyzed using statistical package for social science (SPSS). Differences between groups were compared using analysis of variance, ANOVA $(\mathrm{P}<0.05)$ followed by Duncan's Multiple Range Test.

\section{Results}

\subsection{Qualitative phytochemical composition of plant used for water purification}

The qualitative phytochemical composition of the seed, leaf, bark and stem of Citrus limon, Citrus aurantifolia, Citrus sinensis, are presented in Table 1: The leaf and bark of Citrus aurantifolia and the bark of Citrus limon contains all the phytochemicals tested. Steroids, alkaloids were present in all parts of the three plant. Anthraquinone was present in all parts of Citrus limon and absent in all part of Citrus sinensis. Cardiac glycosides and terpenes were present in all part of Citrus sinensis. Phenol, flavonoids and tannins were present in leaf, bark and stem of Citrus aurantifolia, Phenol, flavonoids, saponins, tannins, Cardiac glycosides and anthraquinone were absent in seed of Citrus aurantifolia.

\subsection{Biochemical characteristic and frequency of occurrence of the Bacterial isolates}

A total of 10 different bacteria isolates including; Eshecherichia coli, Shigella dysennteriae, Salmonella spp, Staphyloccocus aureus, Klebsiella pneumonia, Bacillus megatarium, Pseudomonnas aeruginosa, Kluyvera ascorbate, Proteus myxofaciens and Enterobacter aerogenes were identified from ponds water samples.

Table 1 Phytochemical composition of citrus plant species used for water purification

\begin{tabular}{|c|c|c|c|c|c|c|c|c|c|c|}
\hline Plant & $\stackrel{\pi}{\pi}$ & $\frac{n}{\frac{n}{0}}$ & $\begin{array}{l}\frac{n}{0} \\
0 \\
0 \\
0 \\
0 \\
\vdots\end{array}$ & 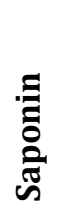 & 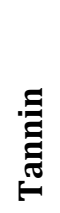 & $\frac{y}{\frac{n}{0}}$ & 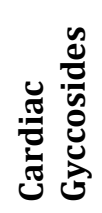 & 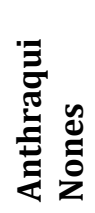 & 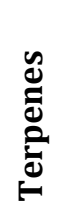 & $\begin{array}{l}\frac{\sigma}{0} \\
\frac{0}{0} \\
\frac{\pi}{4}\end{array}$ \\
\hline \multirow[t]{4}{*}{ Citrus limon } & Seed & - & - & - & - & + & - & + & - & + \\
\hline & Leaf & + & - & - & + & + & - & + & + & + \\
\hline & Bark & + & + & + & + & + & + & + & + & + \\
\hline & Stem & + & - & - & + & + & - & + & + & + \\
\hline \multirow[t]{4}{*}{ Citrus aurantifolia } & Seed & - & - & - & - & + & - & - & + & + \\
\hline & Leaf & + & + & & + & + & + & + & + & + \\
\hline & Bark & + & + & + & + & + & + & + & + & + \\
\hline & Stem & + & + & + & + & + & - & - & - & + \\
\hline \multirow[t]{4}{*}{ Citrus sinensis } & Seed & - & - & - & - & + & + & - & + & + \\
\hline & Leaf & + & + & - & - & + & + & - & + & + \\
\hline & Bark & - & + & - & + & + & + & - & + & + \\
\hline & Stem & - & + & - & - & + & + & - & + & + \\
\hline
\end{tabular}

\subsection{Effect of citrus plants on bacteriological quality of pond water}

The untreated pond water had the TVC of $6.10 \pm 0.04 \times 10^{5} \mathrm{cfu} / \mathrm{ml}, 3.30 \pm 0.56 \times 10^{5} \mathrm{cfu} / \mathrm{ml}$ and $3.30 \pm 0.03 \times 10^{5} \mathrm{cfu} / \mathrm{ml}$ at 0 , 12 and $12 \mathrm{~h}$ respectively, TCC were $2.96 \pm 0.24 \times 10^{3} \mathrm{cfu} / \mathrm{ml}, 2.96 \pm 0.03 \times 10^{3} \mathrm{cfu} / \mathrm{ml}$ and $2.96 \pm 0.03 \times 10^{3} \mathrm{cfu} / \mathrm{ml}$ at $0,12 \mathrm{and}$ $24 \mathrm{~h}$ respectively, FCC were $250.34 \pm 0.89 \mathrm{mpn} / 100 \mathrm{ml}, 250.24 \pm 3.45 \mathrm{mpn} / 100 \mathrm{ml}$ and $250.56 \pm 2.87 \mathrm{mpn} / 100 \mathrm{ml}$ at 0,12 and $24 \mathrm{~h}$ respectively while SSC were $1.68 \pm 0.03 \times 10^{3} \mathrm{cfu} / \mathrm{ml}, 1.68 \pm 0.03 \times 10^{3} \mathrm{cfu} / \mathrm{ml}$ and $1.68 \pm 0.03 \times 10^{3} \mathrm{cfu} / \mathrm{ml}$ at 0,12 and $24 \mathrm{~h}$ respectively (Table 2 ).

The stem, seed, leaf and bark materials of Citrus aurantifolia at concentrations of $0.3,0.4$ and $0.5 \mathrm{~g} / \mathrm{l}$ produced a complete elimination of the bacteria from the pond water after 24 hours of treatment. Only the stem material produces a complete elimination of the organism at $12 \mathrm{~h}$ (table 2).

The leaf and bark materials of Citrus limon at all concentrations tested $(0.1,0.2,0.3,0.4$ and 0.5 g/L) completely eliminated the various bacteria from of the pond water after 24 hours of treatment. However, the stem and seed were less active; only concentrations of 0.4 and $0.5 \mathrm{~g} / \mathrm{L}$ caused the elimination of the organism after $24 \mathrm{~h}$ of treatment (Table 3). 


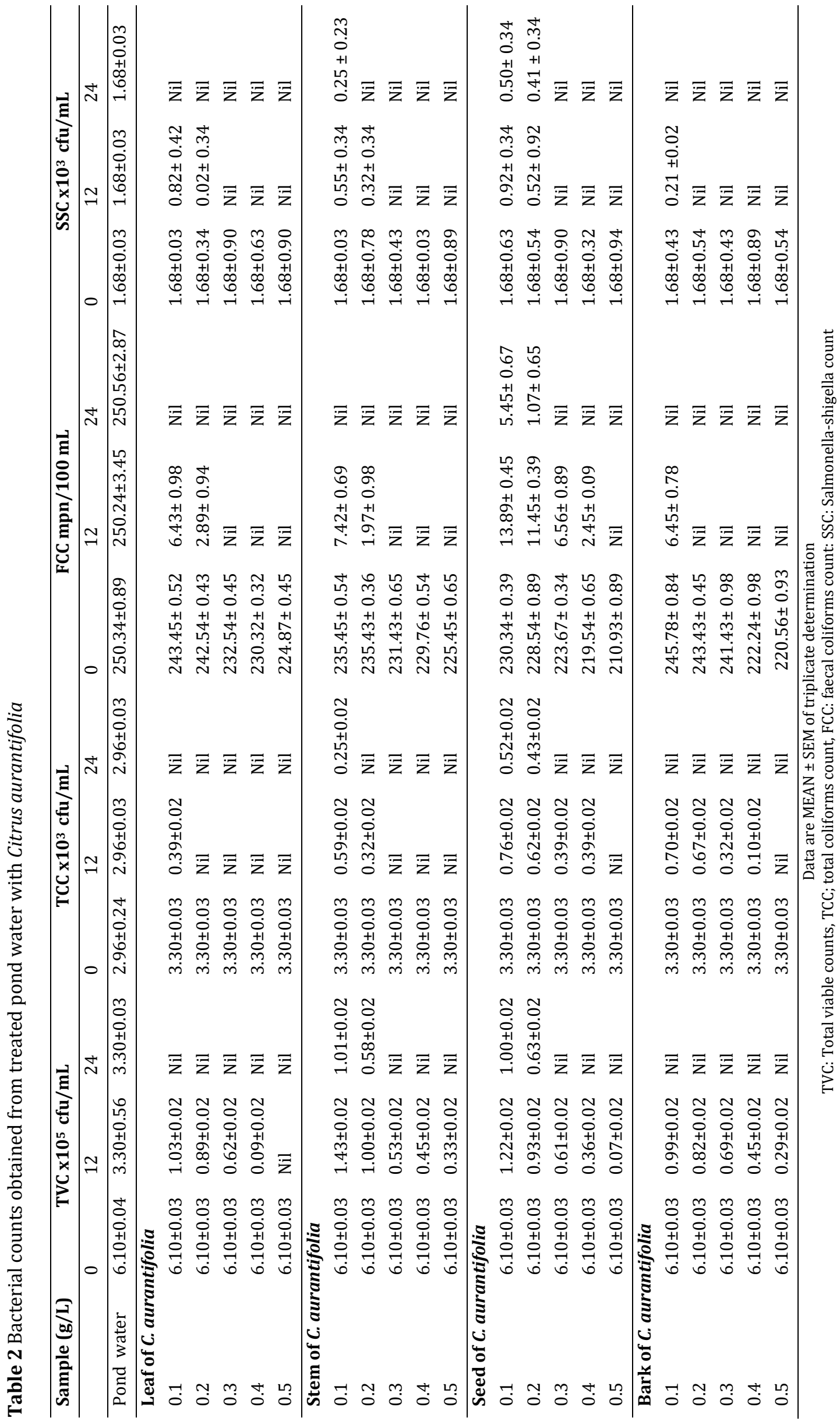




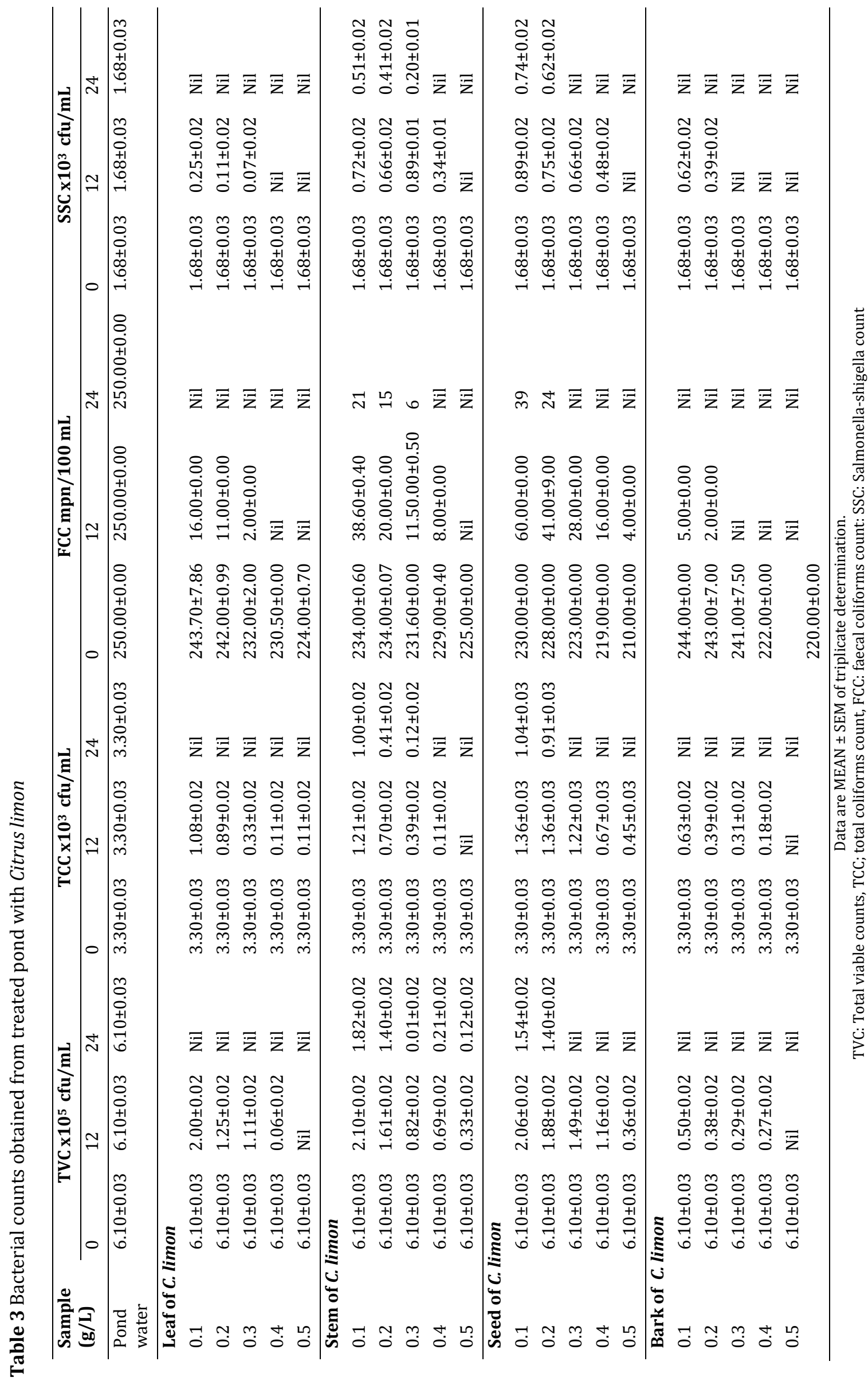




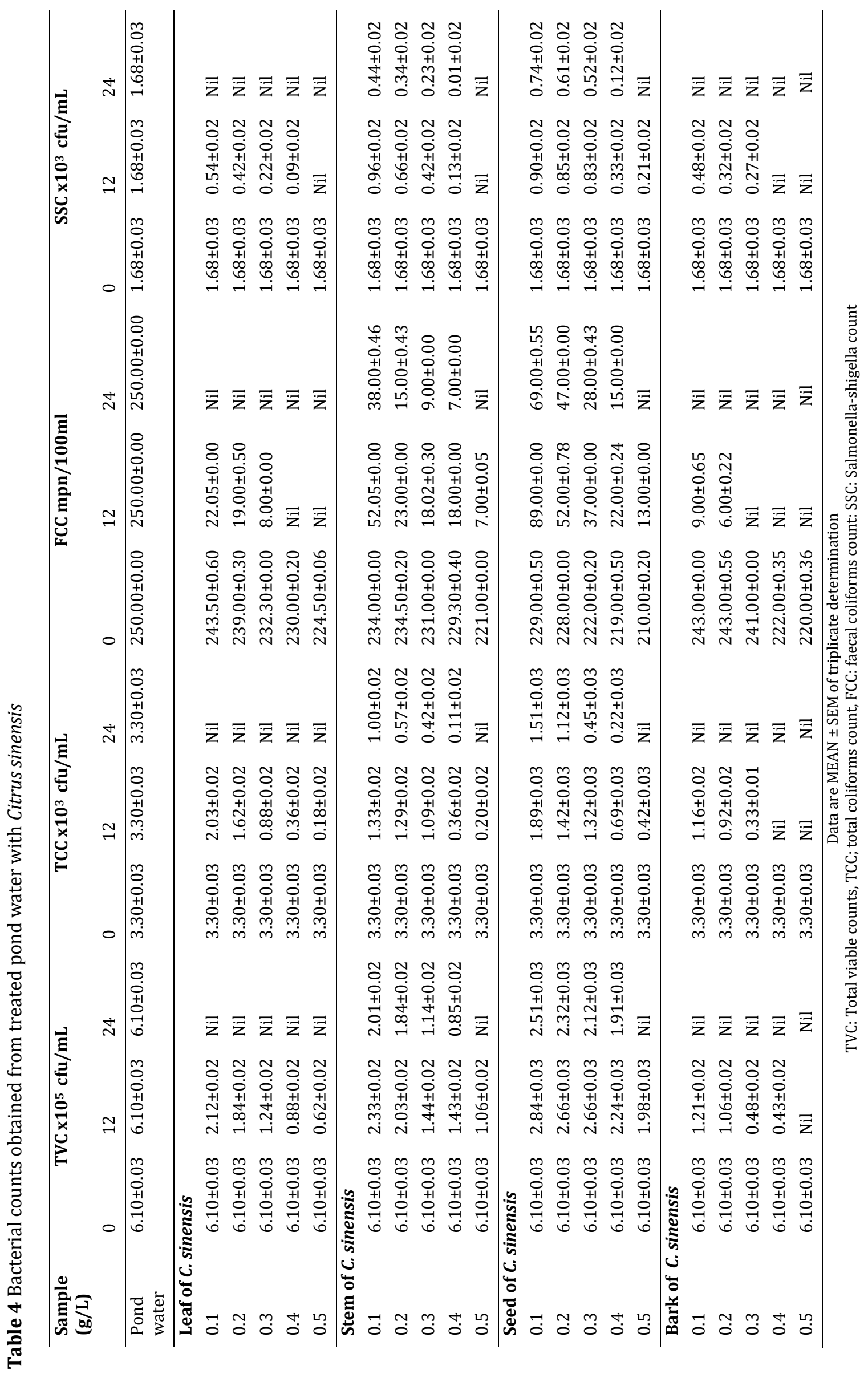



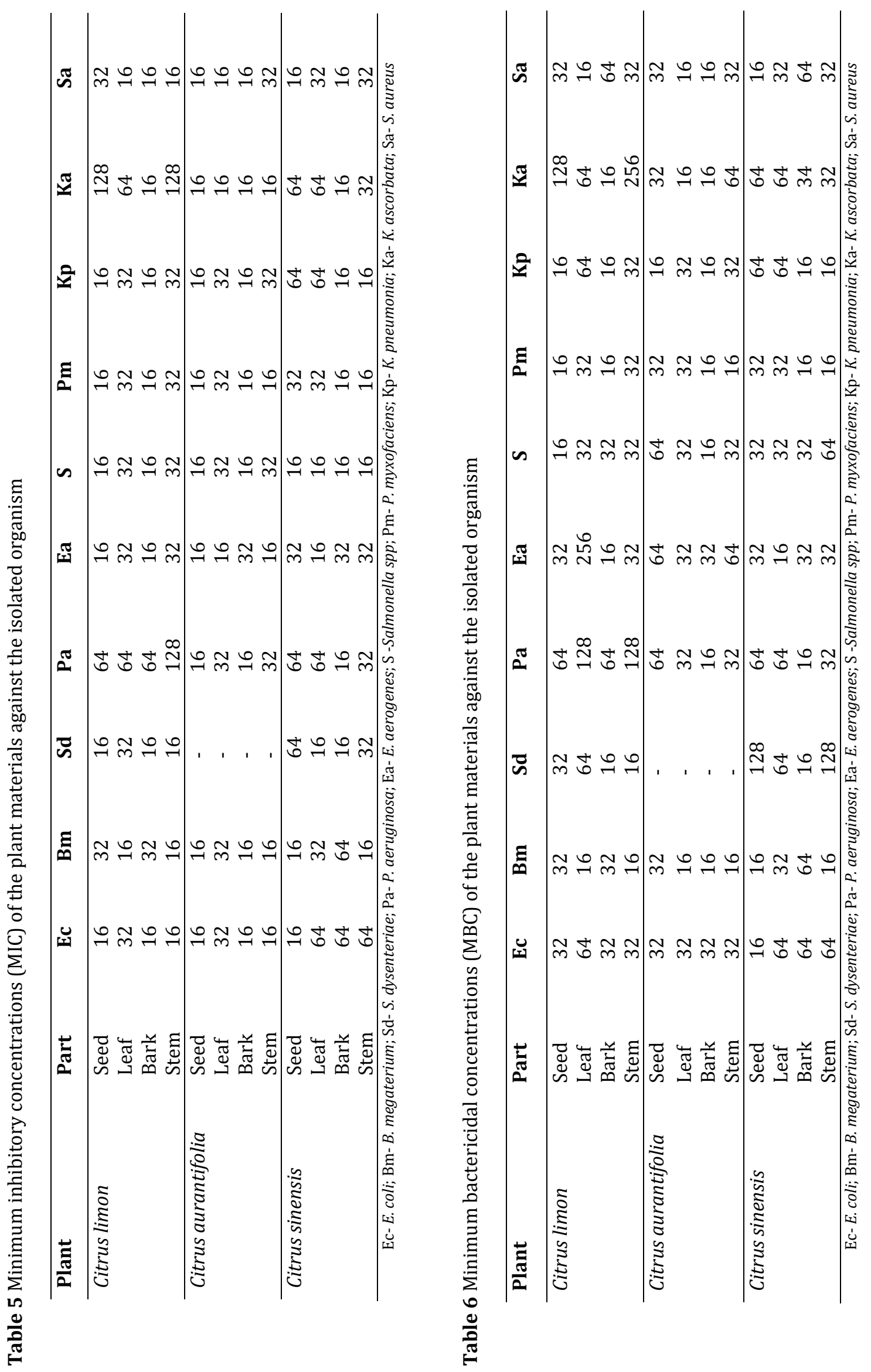
Okunlola et al. / GSC Biological and Pharmaceutical Sciences 2019, 08(02), 034-044

The leaf and bark materials of Citrus sinensis at all concentrations tested $(0.1,0.2,0.3,0.4$ and $0.5 \mathrm{~g} / \mathrm{L})$ completely eliminated the various bacteria from of the pond water after 24 hours of treatment. However, the stem and seed were less active; only concentrations of $0.5 \mathrm{~g} / \mathrm{L}$ caused the elimination of the organism after $24 \mathrm{~h}$ of treatment (Table 4 ).

\subsection{Minimum inhibitory concentrations (MIC) and Minimum bacterialcial concentrations (MBC)}

The minimum inhibitory concentrations (MIC) of the citrus plant materials against the isolated organism are presented in table 5. The MIC range between 16 and 128 against all the isolates tested. Citrus aurantifolia materials were inactive against $S$. dysenteriae. The minimum bactericidal concentrations (MIC) of Citrus limon, Citrus aurantifolia and Citrus sinensis material (seed, leaf, bark and stem) against the isolated organism are range between 16 and 256 against all the isolates tested (table 6).

\section{Discussion}

Plants constitute an important source of active ingredients known as secondary metabolite which confers to them some physical characteristic and also defense purposes [23]. However, these metabolites have been reported for various beneficial properties to humanity [24]. The photochemical screening of citrus plants indicated the presence various phytochemicals which have been implicated in various biological activities [24-25]

The phytochemical composition observed in leaf, stem, seed and bark (Table 1) of Citrus species (Citrus limon, Citrus aurantifolia, Citrus sinensis) is in line with previous studies which reported that citrus plants synthesize and accumulate in their cells a great variety of phytochemicals including low molecular phenolic (hydroxy benzoic and hydroxycinnamic acids, acetophenones, terpenoids, flavonoids, stilbenes and condensed tannins [14-15]. There are about 40 limonoids in citrus with limonin and nomilin being the principal ones [26]. Flavonoids from natral products particularly plants extract have been reported for antimicrobial and antioxidants properties [27]. The flavonoids contents of citrus plant as observed in this study have been reported to possess strong inherent ability to modify the body's reaction to microorganism [14]. this will be a very useful property in the microbial decontamination of surface water. Quercetin, myricitin, rutin, tangeritin, naringin and hesperidin are found amongst the common flavonoids in citrus fruits [15].

The leaves, fruits, stems and roots of citrus sp like C. aurantufolia, C. aurantium, C. paradise Macfed and C. Sinensis are employed in the treatment of malaria and fever in herbal medicine [28]. The medicinal properties of these phytochemicals present in the citrus plant will be an added advantage to the quality of water when these plants are used for purification, as it will confer medicinal properties to the purified water.

The present study also found that anthraquinone and saponine was completely absent in Citrus sinensis leaf, stem, seed and bark. Javed et al., [29], however reported the presence of terpenoids, flavonoids, alkaloids, glycosides, saponins and steroids in the peel of Citrus reticulate fruit. This discrepancy could be associated with the findings of earlier researcher who reported that not all phytochemicals are present in all plant and that those present differ with the organs or parts of the plant [30].

Bacterial species identified in the river, stream and pond water samples (untreated) were mostly members of Enterobacteriaceae family. These bacterial species include Salmonella, E. coli, Klebsiella, Proteus, Pseudomonas, Enterobacter. Citrobacter freundii. These bacterial isolates were found to be similar to those that are commonly observed in contaminated water bodies and other aquatic environments. Prasai et al., [31], also identified Escherichia coli, Enterobacter spp, Citrobacter spp, Pseudomonas aeruginosa, Klebsiella spp, Shigella spp, Salmonella typhi, Proteus vulgaris, Serratia spp, and Vibrio cholera in water samples from Kathmandu valley, Nepal

The mean viable counts of pond water samples recorded in this study were generally higher than the set standard for water meant for drinking purposes by WHO, [32], and EU, [33]. The presence of these bacterial species in the water samples possibly suggest that the pond water in the study area have been contaminated with wastes either of human or animal origin. This means that using this water without treatment could be hazardous to human and animal health. This observation is line with the studies conducted on surface water in Malawi by Pritchard et al. [34], in Bamenda, Cameroun by Yongabi et al. [35], in Abeokuta, Ogun State, Nigeria by Ojekunle et al. [36] and in Guma Local Government Area, Benue State, Nigeria by Ichor et al. [37]

Drinking water contaminated with these organisms can cause stomach and intestinal illness including diarrhea and nausea, and even lead to death. These effects may be more severe and possibly life threatening for babies, children, the elderly or people with immune deficiencies or other illnesses [34] 
Citrus limon also demonstrated significant activity, the leaf and bark material of Citrus limon at all concentrations tested $(0.1,0.2,0.3,0.4$ and $0.5 \mathrm{~g} / \mathrm{l})$ completely eliminated the bacteria from the stream water after 24 hours of treatment. However, the stem and seed only show complete elimination at concentrations of 0.4 and $0.5 \mathrm{~g} / \mathrm{l}$ (Table 2). Citrus sinensis also produced considerable decontamination of the microbial load from the stream water, However, the stem and seed material significantly $(\mathrm{p}<0.05)$ reduced the amount of the bacteria count but could not attend complete elimination, even at the highest doses ( $0.5 \mathrm{~g} / \mathrm{l})$ (Table 3). This finding reflect increased concentration of antimicrobial agent as the treatment dose increased, this is in line with the findings of Yusuf et al., [38], Tsado et al., [39], Ibrahim et al., [40], who reported that increased in concentration of plant material resulted in corresponding decreased in bacterial load. This finding is in line with the previous studies that reported that Citrus sinensis, Citrus aurantifolia and Citrus limon showed a very good antimicrobial activity against E. coli, S. typhi, B. subtilis, K. pnemonia and S. aureus [41]. This antibacterial activity may be indicative of the presence of metabolic toxins or broad spectrum antibiotic compounds Amandeep et al [41]. Ekwenye and Edeha [42], reported antibacterial activity of Citrus sinensis leaf against the test organisms taken in their study (E. coli, K. pneumoniae, S. aureu).

MIC is the lowest concentration of antibacterial substance required to produce a sterile culture [20]. It is worthy of note that MBC values obtained for the plant materials against the pathogens are higher than MIC, indicating that the plant materials are bacteriostatics at lower concentrations and bactericidal at higher concentrations [43]. This suggests that these plant materials, when used traditionally as antimicrobials inhibit bacteria growth without necessarily killing the bacteria and since most of the traditional preparations lack specific concentrations, this may thus account for the use of large quantity of the extracts by traditional medical practitioners for the treatment of their patients. In this study, the growth of $P$. aeruginosa, $S$. aureus, and E. coli, which are already known to be multi-resistant to different antibiotics, was inhibited by the citrus plants species, thus indicating the antimicrobial activities of the plants against diverse organism.

\section{Conclusion}

It is concluded that the leaf, stem bark and seed of citrus species contains various phytochemicals and have the potentials to serve as a disinfectant for water treatment. The need to exploit the potential of these citrus plants may offer cheap, and environment friendly methods of tackling water contamination and may possibly overcome the hazards of using synthetic compounds.

\section{Compliance with ethical standards}

\section{Acknowledgments}

The authors would like to appreciate the Tertiary Educational Trust Fund of Nigerian and Federal University of Technology Minna for the research grant (TETFUND/FUTMINNA)/2017/05).

\section{Disclosure of conflict of interest}

The authors declared no conflict of interest exist.

\section{References}

[1] Jodi ML, Birnin-Yauri UA, Yahaya Y and Sokoto MA. (2012). The use of some plants in water purification. Global Advanced Research Journal of Chemistry and Material Sciences, 1(4), 71-75.

[2] Kihampa C, Mwegoha WJS, Kaseva ME and Marobhe N. (2011). Performance of Solanum incunum L. as natural coagulant and disinfectant for drinking water. African Journal of Environmental Science and Technology 5(10), 867-872.

[3] UNICEF/WHO. (2012). Joint monitoring program for water supply and sanitation estimates for the use of improved drinking-water sources Ethiopia. 13.

[4] Megersa M, Beyene A, Ambelu A and Woldeab B. (2014). The use of indigenous plant species for drinking water treatment in developing countries: a review. Journal of Biodiversity and Environmental Sciences (JBES), 5(3), 269-281.

[5] WHO. (World Health Organization) (2011). Evaluating household water treatment options: Health-based targets and microbiological performance specifications, Geneva. 
[6] Bashir L, Shittu OK, Sani S, Busari MB and Adeniyi KA. (2015). African natural products with potential antitrypanosoma properties: A review. International Journal of Biochemistry Research \& Review, 7(2), 45-79.

[7] Lawal B, Shittu OK, Kabiru AY, Jigam AA, Umar MB, Berinyuy EB and Alozieuwa BU. (2015). Potential antimalarials from African natural products: A review. Journal of Intercultural Ethnopharmacology, 4(4), 318343.

[8] Yongabi KA. (2010). Biocoagulants for water and waste water purification: a review. International Review of Chemical Engineering, 2, 444-458.

[9] Lawal B, Shittu OK, Oibiokpa IF, Mohammed H, Umar SI and Haruna GM. (2016). Antimicrobial evaluation, acute and sub-acute toxicity studies of Allium sativum. Journal of Acute Disease, 5(4), 296-301.

[10] Tsado AN, Lawal B, Ossai PC, Jagaba A, Gwadabe NK, Jiya AG, Umar AM and Oladunjoye JO. (2016). Antioxidants and antimicrobial activities of methanol extract of Newbouldia laevis and Crateva adansonii. Journal of Pharmacy and Allied Health Sciences, 6, 14-19.

[11] Bichi MH. (2013). A Review of the applications of Moringa oleifera seeds extract in water treatment. Civil and Environmental Research, 3(8), 1-10.

[12] Edogbanya PRO, Ocholi OJ and Apeji Y. (2013). A review on the use of plants' seeds as biocoagulants in the purification of water. Continental Journal of Biological Science, 6(2), $26-32$.

[13] Azhari AMN. (2017). Phytochemical screening and antibacterial activity of cultivated medicinal plants Citrus paradise. Chemistry Research Journal, 2(2), 73-77.

[14] Okwi DE and Emenike IN. (2006). Evaluation of the phytonutrients and vitamins contents of citrus fruits. International Journal of Molecular Medicine and Advance Sciences, 2(1), 1-6.

[15] Okwu DE. (2008). Citrus fruits: a rich source of phytochemicals and their roles in human health. International Journal of Chemistry and Science, 6(2), 451-471.

[16] Harborne JB. (1998). Phytochemical methods: A guide to modern technique of plant analysis. 3 ${ }^{\text {rd }}$ Edn, Springer, London, 88-185.

[17] Trease GE and Evans WC. (1983). Textbook of Pharmacognosy. 12 ${ }^{\text {th }}$ Edn., Bailliere Tindall, London, 34.

[18] American Public Health Association (APHA) (1999). Standard methods for the examination of water and wastewaters, 20 $0^{\text {th }}$ ed., APHA, Washington D.C, 1134.

[19] Vandepitte J, Verhaegen J, Engbaek K, Rohner P, Piot P and Heuck CC. (2003). Basic laboratory procedures in clinical bacteriology $2^{\text {nd }}$ ed. World Health Organization Geneva, Switzerland, 42-59.

[20] Cheesbrough M. (2008). District laboratory practice in tropical countries part 2. Cambridge University Press, New Delhi, India, 62-70.

[21] McConnachie GL, Folkard GK and Mtawali MA. (1999). Sutherland JP. Field Trials of Appropriate Hydraulic Flocculation Processes. Water Research, 33 (6), 1425-1434.

[22] Eloff JN. (1998). A sensitive and quick microplate method to determine the minimal inhibitory concentration of plant extracts for bacteria. Planta Medica, 64, 711-3.

[23] Adeniyi KA, Olayemi IK, Shittu KO, Busari MB, Mohammed SS, Bashir L and Yusuf RS. (2015). Comparative phytochemical and antinutritional constituents of Nigeria sweet and bitter honey varieties. World Journal of Pharmaceutical Research, 5(3), 255-267.

[24] Tsado NA, Lawal B, Santali ES, Mohammed AS, Balarabe MM, Ibrahim HA and George JJ. (2015). Phytochemicals and acute toxicity profile of aqueous and methanolic extracts of Crateva adansonii leaves in Swiss Albino rats. Asian Journal of Biochemistry. Asian Journal of Biochemistry, 10 (4), 173-179.

[25] Ibrahim AM, Lawal B, Tsado NA, Yusuf AA and Jimoh AM. (2015). Phytochemical screening and GC-MS determination of bioactive constituents from methanol leaf extract of Senna occidentalis. Journal of Coastal Life Medicine, 3(12), 992-995.

[26] Craig EJ. (2002). Phytochemical guardians of our health. Journal of American Dietetic Association, 97(2), 199204.

[27] Lawal B, Shittu OK, Oibiokpa FI, Berinyuy EB and Muhammed H. (2016). African natural products with potential antioxidants and hepatoprotectives properties: a review. Clinical Phytoscience, 2(23), 1-66. 
[28] Adesegun SA and Coker HAB. (2001). Plants used in traditional medicine against malaria. Nigeria J. Pharma. 32, 50-62.

[29] Javed S, Javaid A, Nawaz S, Saeed MK, Mahmood Z, Siddiqui SZ and Ahmad R. (2014). Phytochemistry, GC-MS analysis, antioxidant and antimicrobial potential of essential oil from five citrus species. Journal of Agricultural Science, 6(3), 201-208.

[30] Lawal B, Ossai PC, Shittu OK and Abubakar AN. (2014). Evaluation of phytochemicals, proximate, minerals and anti-nutritional compositions of yam peel, maize chaff and bean coat. International Journal of Applied Biological Research, 6(2), 1-17.

[31] Prasai T, Lekhak B, Joshi DR and Baral MP. (2007). Microbiological analysis of drinking water of Kathmandu Valley. Scientific World, 5, 112-114.

[32] World Health Organization (WHO) (1993). Guideline of drinking water quality, $2^{\text {nd }}$ ed. Health criteria and other supporting information. WHO, Geneva, Switzerland, 162.

[33] European Union (EU). (1998). Council directive on the quality of water intended for human consumption. J. Eur. Communit. 330, 32-54.

[34] Pritcharda T, Mkandawireb A, Edmondsona JG, O’Neillc G and Kululang. (2009). Potential of using plant extracts for purification of shallow well water in Malawi. Physics and Chemistry of the Earth, 34, 799-805.

[35] Yongabi KA, Lewis DM and Harris PL. (2011). Application of phytodisinfectants in water purification in rural Cameroun. African Journal of Microbiology Research, 5(6), 628-635.

[36] Ojekunle ZO, Ufoegbune GC, Oyebamiji FF, Sangowusi RO, Taiwo AM and Ojekunle VO. (2014). Assessment of the effect of commercial activities on the surface water quality of Ogun River, Nigeria. Merit Research Journal of Environmental Sciences and Toxicology, 2(9), 196-204.

[37] Ichor T, Umeh EC and Duru EE. (2014). Microbial contamination of surface water sources in rural areas of guma local government area of Benue State, Nigeria, Medical Sciences and Public Health, 2(2), 43-51.

[38] Yusuf AA, Lawal B, Abubakar AN, Berinyuy EB, Omonije YO, Umar SI, Shebe MN and Alhaji YM. (2018). In-vitro antioxidants, antimicrobial and toxicological evaluation of Nigerian Zingiber officinale. Clinical Phytoscience, 4, 12, 1-8.

[39] Tsado NA, Lawal B, Kontagora GN, Muhammad BM, Yahaya MA, Gboke JA, Muhammad UA and Hassan MK. (2016). Antioxidants and antimicrobial- activities of methanol leaf extract of Senna occidentalis. Journal of Advances in Medical and Pharmaceutical Sciences. 8(2), 1-7.

[40] Ibrahim AM, Lawal B, Abubakar AN, Tsado NA, Kontagora GN, Gboke GA and Berinyuy EB. (2017). Antimicrobial and free radical scavenging potentials of n-hexane and ethyl acetate fractions of Phyllanthus fraternus. Nigerian Journal of Basic and Applied Science, 25(2), 06-11.

[41] Amandeep S, Ahmed R, Bilal and Anil D. (2009). In vitro antibiotic activity of isolated volatile oil of Citrus sinensis. International Journal Pharma Research Development, 1(7), 1-4.

[42] Ekwenye UN and Edeha OV. (2010). The anti-bacterial activity of crude leaf extract of Citrus sinensis (sweet orange). Int. J. Pharm. Bio. Sci, 1(4), 742-750.

[43] Fisher K and Phillips C. (2008). Potential antimicrobial uses of essential oils in food: is citrus the answer? Trends in Food Science and Technology, 19, 156-164.

\section{How to cite this article}

Okunlola BM, Ijah UJJ, Yisa J and Abioye OP. (2019). Phytochemical and phyto-disinfectant properties of citrus species (Citrus limon, Citrus aurantifolia and Citrus sinensis) for pond water purification. GSC Biological and Pharmaceutical Sciences, 8(2), 34-44. 